\title{
Pre-S2 Deletions of Hepatitis B Virus and Hepatocellular Carcinoma in Children
}

\author{
HSIANG-PO HUANG, HONG-YUAN HSU, CHI-LING CHEN, YEN-HSUAN NI, HURNG-YI WANG, DAW-JEN TSUEI, \\ CHENG-LUN CHIANG, YI-CHEN TSAI, HUEY-LING CHEN, AND MEI-HWEI CHANG
}

Department of Medical Research [H.-P.H., Y.-C.T.], National Taiwan University Hospital; Department of Pediatrics [H.-Y.H., D.-J.T., C.-L.C., H.-L.C., Y.-H.N., M.-H.C.], National Taiwan University Children's Hospital; Graduate Institute of Clinical Medicine [C.-L.C., H.-Y.W.], National Taiwan University, Taipei 100, Taiwan

\begin{abstract}
The cause of early oncogenesis in hepatitis B virus (HBV)-related childhood hepatocellular carcinoma (HCC) remains unclear. This study investigated whether pre-S deletion of HBV is related to childhood HCC. By using nested polymerase chain reaction, we compared the pre-S sequence of HBV from sera of children with HCC against control children with similar chronic HBV infection. The HBV in sera of children with HCC had a significantly higher rate of pre-S deletion than that of children with chronic HBV infection $(p=0.008)$. All except one of the pre-S deletions from the HCC group involved the pre-S2 region, whereas no pre-S2 deletion was found in the chronic HBV group $(p=0.003)$. There was a trend whereby genotype-C sera had a higher rate of pre-S2 deletion than genotype-B sera $(p=0.11)$. A multivariate logistic regression model revealed that pre-S deletion was an independent risk factor for HCC in children (odds ratio: $36.69, p=0.015$ ). In conclusion, pre-S2 deletion does not need to take decades to occur; its presence in nearly half of children with HCC, in contrast to its absence in children with chronic HBV infection, suggests a link between pre-S2 deletion and HCC development in children. (Pediatr Res 67: 90-94, 2010)
\end{abstract}

$\mathrm{C}$ hronic hepatitis B virus (HBV) infection, which potentially causes severe complications, such as liver cirrhosis and hepatocellular carcinoma (HCC) (1), is a grave threat to human health in hyperendemic regions. Patients with chronic HBV infection undergo variable clinical courses and have different outcomes. One such outcome is the development of HCC in children after a relatively short period of HBV infection; they are mostly $\mathrm{HBV}$ e antigen ( $\mathrm{HBeAg}$ ) negative and anti-HBe positive at the diagnosis of HCC (2). However, the key risk factors responsible for $\mathrm{HCC}$ development, particularly the early onset of HCC in children, remain largely unclear.

In children with chronic HBV infection, some specific HBV genotypes and mutations in the HBV genome have been shown to have significant impact on the clinical course or outcome (3-5). Genotype B predominates in children with both chronic HBV infection and HCC in Taiwan, whereas genotype $\mathrm{C}$ delays $\mathrm{HBeAg}$ seroconversion (4). In addition,

Received July 14, 2009; accepted September 7, 2009.

Correspondence: Mei-Hwei Chang, M.D., Department of Pediatrics, National Taiwan University Children's Hospital, 8, Chung-Shan South Road, Taipei 100, Taiwan; e-mail: changmh@ntu.edu.tw

Support by National Science Council (NSC-96-2628-B002-017-MY3) and the National Health Research Institutes (NHRI-EX97-9418BI) of Taiwan.

Supplemental digital content is available for this article. Direct URL citations appear in the printed text and are provided in the HTML and PDF versions of this article on the journal's Web site (www.pedresearch.org). children with earlier emergence of the precore stop codon mutant (G1896A) tend to have more severe hepatocellular damage (3) and account for about half of childhood HBeAg seroconversion (5). In the core promoter region, higher rates of A1775G and G1799C mutations and a lower rate of the A1752G mutation have been found in childhood HBeAg seroconverters (5). In the core gene region, children with HCC have more mutations than those with chronic HBV infection (6); in addition, the HCC group has mutation hotspots at core gene codons 74, 87, and 159, whereas the chronic HBV group has mutation hotspots at core gene codons 21, 65, and 147 (6).

In an attempt to identify a broader spectrum of important features of HBV genomes linked to childhood HCC, we had previously sequenced the whole genome of HBV isolated from the serum of three children with HCC and found that one of them contained a pre-S deletion in the HBV genome. Therefore, in this study, we compared the pre-S region between children with HBV-related HCC and with chronic HBV infection to investigate if pre-S deletion is associated with HCC development in children. In addition, because adult HBV carriers with either basal core promoter mutation (A1762T and G1764A) or precore mutation (G1896A) have been shown to have a higher risk for $\operatorname{HCC}(7,8)$, we also determined the prevalence of both mutations in our patients and included these data with that of pre-S deletion in a multivariate analysis.

\section{PATIENTS AND METHODS}

Children with HCC. Nineteen children (male:female = 13:6) with HBVrelated HCC who were diagnosed before the age of 15 were included in this study. The majority of cases (15/19) had pathologic samples, and the diagnosis of HCC was made by pathologists in our hospital. For the other four patients who refused liver biopsy due to the advanced stage of the disease, the older age of onset, a positive maternal HBV surface antigen (HBsAg), elevated alpha-fetoprotein levels, and imaging studies, including sonography, computed tomography, and magnetic resonance imaging, confirmed the diagnosis according to the guideline of the American Association for the Study of Liver Diseases (9). After the diagnosis of HCC, the follow-up period ranged from 1 mo to $24.5 \mathrm{y}$. Blood samples were drawn immediately after the establishment of diagnosis (average age: $12.7 \pm 6.6 \mathrm{y}$ ).

Control group: children with chronic $\mathrm{HBV}$ infection. We longitudinally followed up $415 \mathrm{HBsAg}$ carrier children who were less than 15-y old at

\footnotetext{
Abbreviations: HBeAg, hepatitis B virus e antigen; HbsAg, hepatitis B virus surface antigen; HBV, hepatitis B virus; HCC, hepatocellular carcinoma; PHSA, polymerized human serum albumin
} 
Table 1. Summary of clinical and virologic characteristics in children with HCC and chronic HBV infection

\begin{tabular}{lccc}
\hline & HCC group & CH group & $p$ \\
\hline$N$ & 19 & 19 & - \\
Gender (M:F) & $13: 6$ & $13: 6$ & - \\
Age (mean \pm SD) & $12.7 \pm 6.6$ & $12.3 \pm 0.8$ & $0.770^{*}$ \\
HBsAg (+) (\%) & $19(100)$ & $19(100)$ & - \\
Anti-HBe (+) $(\%)$ & $16(88.8)^{\dagger}$ & $17(89.5)$ & 1 \\
Genotype (B:C) & 14.5 & $14: 5$ & - \\
Viral load & $3.5 \pm 0.8$ & $3.7 \pm 1.8$ & $0.676^{*}$ \\
$\quad[$ log (copies/mL) & & & \\
Total pre-S deletion $(\%)$ & $9(47.4)$ & $1(5.3)$ & 0.008 \\
Pre-S1 deletion $(\%)$ & $4(21.1)$ & $1(5.3)$ & 0.340 \\
Pre-S2 deletion $(\%)$ & $8(42.1)$ & $0(0.0)$ & 0.003 \\
BCP mutation $(\%)$ & $7(36.8)$ & $4(21.1)$ & 0.476 \\
Precore mutation $(\%)$ & $9(47.4)$ & $4(21.1)$ & 0.170 \\
\hline
\end{tabular}

All other $p$ values calculated by Fisher's exact test.

* Calculated by Student's $t$-test.

${ }^{\dagger}$ The data for this item were not available in one patient; the percentage was calculated as 16 of 18

$\mathrm{N}$, numbers of patients with PCR-amplifiable serum HBV pre-S sequences; $\mathrm{CH}$, chronic $\mathrm{HBV}$ infection; $\mathrm{BCP}$, basal core promoter.

enrollment. Among them, we randomly selected 19 age- and gender-matched children (Table 1) to compare the serum HBV pre-S sequence with the same sequence in 19 cases of HCC. There was no difference between the control group and the HCC group in terms of the rate of $\mathrm{HBeAg}$ seroconversion (HBeAg seronegative and anti-HBe seropositive) and the distribution of $\mathrm{HBV}$ genotypes. We did not know the status of their basal core promoter and precore mutations before the study.

Determination of $H B V$ genotypes and viral loads. Serum HBV genotypes were determined by polymerase chain reaction (PCR) with genotype-specific primers as described previously (10). The viral load (HBV DNA quantification, copies $/ \mathrm{mL}$ ) was determined by real-time PCR as described previously (10). The sensitivity of this method was $10^{3}$ copies $/ \mathrm{mL}$.

Extraction of DNA from sera. Serum DNA was extracted from $200 \mu \mathrm{L}$ serum by QIAamp DNA mini kit (Qiagen), following the instructions of the manufacturer. The DNA was dissolved in $100 \mu \mathrm{L}$ double-distilled water.

Nested PCR to amplify the pre-S region and direct sequencing. To amplify the pre-S region of HBV, we performed nested PCR with two pairs of HBV genotype B and genotype C-co-positive primers (PS1/PS2 for the first round, PS3/PS4 for the second round) (11). The primers were as follows: PS1 (nt 2814-2839): 5'-GGGTCACCTTATTCTTGGGA-3', PS2 (nt 208-189): 5'-CCCCGCCTGTAACACGAGCA-3', PS3 (nt 2828-2847): 5'-TTGGGAACAAGATCTACAGC-3', and PS4 (nt 176-157): 5'-GTCCTGATGCGATGTTCTCC- $3^{\prime}$. The polymerase for PCR was Prime TaqDNA polymerase (Genet Bio., Korea), and the final volume of PCR reactions was $50 \mu \mathrm{L}$. The condition used for PCR was $94^{\circ} \mathrm{C}$ for 2 min, followed by 36 cycles of $94^{\circ} \mathrm{C}$ for $1 \mathrm{~min}, 58^{\circ} \mathrm{C}$ for $30 \mathrm{~s}$, and $72^{\circ} \mathrm{C}$ for $1 \mathrm{~min}$. To amplify the precore/core region of $\mathrm{HBV}$, we performed nested PCR with two pairs of HBV genotype B and genotype C-co-positive primers (PS1/PS2 for the first round, PS3/PS4 for the second round) (11). The primers were as follows: PC1 (nt 1652-1671): 5'-ACATAAGAGGACTCTTGGAC-3', PC2 (nt 19771957): 5'-GAAGGAAAGAAGTCAGAAGGC-3', PC3 (nt 1704-1725): 5' TACTTCAAAGACTGTGTGTTTA-3', and PC4 (1966-1947): 5' -GTCAGAAGGCAAAAAAGAGA-3'. The condition used for PCR was $94^{\circ} \mathrm{C}$ for 2 min, followed by 36 cycles of $94^{\circ} \mathrm{C}$ for $1 \mathrm{~min}, 45^{\circ} \mathrm{C}$ for $30 \mathrm{~s}$, and $72^{\circ} \mathrm{C}$ for 1 min. The amplified PCR products were separated by electrophoresis, and all visible bands were cut and purified from the $1.5 \%$ agarose gel with a Gel/PCR DNA Fragments Extraction Kit (Geneaid Biotech, Taiwan). The PCR products were then sequenced directly. HBV nucleotides were numbered from the EcoRI site. To avoid contamination in PCR, we used distilled water to replace cDNA as the negative control in each PCR reaction and followed the precautions described elsewhere (12) to avoid false positives.

Cloning of PCR products and isolation of plasmid DNA. For two PCR products of the pre-S region containing multiple sequences shown by direct sequencing, the purified PCR products were cloned using the TOPO XL Cloning Kit (Invitrogen/Life Technologies), and the plasmid DNA was extracted with Mini-M Plasmid DNA Extraction System (Viogene Biotek, Taiwan). At least five DNA samples were then sequenced. The representative sequences were selected from the clones that were completely identical to at least one other clone.
Sequence alignment. Sequences were translated and aligned using ClustalW (13), back translated to their corresponding DNA sequences by the TRANSALIGN software of the EMBOSS package (14), and edited manually. The nucleotide and amino acid sequences of the nine HCC-related HBV pre-S region reported in this study are available in the GenBank database under the accession numbers FJ210940, FJ224090-94, and FJ231724-26.

Ethical considerations. All blood samples of the patients in this study were drawn following written informed consent from parents of the patients or the patients themselves. The Ethical Committee of the National Taiwan University Hospital approved the protocol of this study. All sera in this study were processed so as to protect personal information.

Statistical analysis. Fisher's exact test, $t$ test, or $\chi^{2}$ test with Yates' correction were used to test for statistical significance, whenever the most appropriate. The odds ratio and $95 \% \mathrm{CI}$ were estimated by unconditional logistic regression model to evaluate the association of different risk factors with childhood HCC. The Kaplan-Meier method was used to calculate cumulative survival rates, whereas the difference between groups was analyzed using log-rank tests. The statistical analysis was performed using STATA software (version 8.2; Stata Corp, College Station, TX). $p$ values less than 0.05 were considered significant.

\section{RESULTS}

Pre-S deletion is an independent risk factor for children with HCC. By using nested PCR, we successfully amplified and isolated HBV pre-S DNA sequences from the sera of 19 children with HCC and 19 children with chronic HBV infection. The clinical characteristics and the rates of pre-S deletion in PCR-amplifiable patients are shown in Table 1. The age, gender, HBsAg $(+)$ rate, HBV viral load, and genotype distribution of both groups are well matched (Table 1). In contrast, HBV DNA sequence analysis indicated a much higher rate of pre-S deletion occurring in the sera from children with HCC $(47.4 \%, 9$ of 19) than from children with chronic HBV infection $(5.3 \%, 1$ of $19 ; p=0.008)$. In addition, in the HCC group, there was a trend whereby genotype- $C$ sera had a higher rate of pre-S2 deletion than genotype-B sera (4 of 5 vs 4 of $14, p=0.11$ ). We also compared the rate of basal core promoter mutation (A1762T and G1764A) and precore mutation (G1896A) in our patients (Tables 1 and 2) and found no significant difference between HCC and chronic HBV infection groups. A multivariate logistic regression model (Table 2) revealed that only pre-S deletion was an independent risk factor for $\mathrm{HCC}$ in children (odds ratio: $36.69,95 \% \mathrm{CI}$ : $2.04-669.62 ; p=0.015)$. In addition, we compared the

Table 2. A multivariate logistic regression model of risk factors for HBV-related HCC in children

\begin{tabular}{|c|c|c|}
\hline Rick factors & Odds ratio $(95 \% \mathrm{CI})$ & $p$ \\
\hline $\begin{array}{l}\text { Age in } 1 \mathrm{y} \\
\text { increment }\end{array}$ & $1.04(0.87-1.23)$ & 0.701 \\
\hline $\begin{array}{l}\text { Gender } \\
\quad \text { (female } v s \text { male) }\end{array}$ & $0.17(0.01-1.99)$ & 0.156 \\
\hline $\begin{array}{l}\text { HBV genotype } \\
\quad(\mathrm{C} v s \text { B) }\end{array}$ & $0.35(0.03-3.55)$ & 0.375 \\
\hline $\begin{array}{l}\text { HBV viral load } \\
\text { (1-log increment) }\end{array}$ & $0.78(0.34-1.77)$ & 0.553 \\
\hline $\begin{array}{l}\text { Pre-S mutation* } \\
\quad(\text { yes } / \text { no })\end{array}$ & $36.69(2.04-669.62)$ & 0.015 \\
\hline $\begin{array}{l}\text { BCP mutation } \\
\text { (yes/no) }\end{array}$ & $0.80(0.09-7.31)$ & 0.843 \\
\hline $\begin{array}{l}\text { Precore mutation } \\
\quad(\text { yes/no) }\end{array}$ & $5.01(0.63-39.75)$ & 0.127 \\
\hline
\end{tabular}

* Including deletions of pre-S1, pre-S2, and both.

$\mathrm{BCP}$, basal core promoter. 
Table 3. Characteristics of pre-S deletions detected in children with HCC and with chronic HBV infection

\begin{tabular}{|c|c|c|c|c|c|c|}
\hline Patient No. & Age $(y) / g e n d e r$ & Genotype & $\begin{array}{c}\text { Size of } \\
\text { deletion (bp) }\end{array}$ & Location (nt) & Location (aa) & $\begin{array}{l}\text { Detection of } \\
\text { WT pre-S }\end{array}$ \\
\hline \multicolumn{7}{|l|}{$\mathrm{HCC}$} \\
\hline 1 & $12.8 / \mathrm{F}$ & B & 207 & $\begin{array}{l}2938-3087 \\
3211-52\end{array}$ & $\begin{array}{l}\text { Pre-S1 }(31-80), \\
\text { pre-S2 }(3-16)\end{array}$ & Yes \\
\hline 2 & $12.6 / \mathrm{M}$ & $\mathrm{C}$ & 15 & $3205-4$ & Pre-S2 $(1-5)$ & $\mathrm{No}^{*}$ \\
\hline 3 & $9.0 / \mathrm{M}$ & $\mathrm{C}$ & 42 & $8-49$ & Pre-S2 $(7-20)$ & $\mathrm{No}^{*}$ \\
\hline 4 & $12.2 / \mathrm{M}$ & B & 51 & $2-52$ & Pre-S2 $(5-21)$ & Yes \\
\hline 5 & $16.0 / \mathrm{M}$ & $\mathrm{C}$ & 18 & $23-40$ & Pre-S2 (12 - 29) & Yes \\
\hline 6 & $4.8 / \mathrm{M}$ & $\mathrm{B}$ & 27 & $3045-3071$ & Pre-S1 $(67-75)$ & Yes \\
\hline 7 & $8.8 / \mathrm{M}$ & $\mathrm{B}$ & 120 & $3121-25$ & $\begin{array}{l}\text { Pre-S1 }(92-119), \\
\text { pre-S2 }(1-12)\end{array}$ & Yes \\
\hline 8 & $22.4 / \mathrm{M}$ & $\mathrm{C}$ & 48 & $9-56$ & Pre-S2 $(8-23)$ & Yes \\
\hline 9 & $8.7 / \mathrm{M}$ & $\mathrm{B}$ & 117 & $3152-53$ & $\begin{array}{l}\text { Pre-S1 }(102-119) \text {, } \\
\text { pre-S2 }(1-21)\end{array}$ & No* \\
\hline \multicolumn{7}{|l|}{$\mathrm{CH}$ group } \\
\hline 5957 & $13.4 / \mathrm{F}$ & B & 249 & $2848-3096$ & Pre-S1 $(1-83)$ & Yes \\
\hline
\end{tabular}

* Results from direct sequencing, which detected the major sequences but could not rule out the existence of wild-type sequences as the minor population. $\mathrm{CH}$, chronic HBV infection; nt: nucleotide; aa: amino acid; WT: wild-type.

clinical presentation and outcome of pre-S deleted and nondeleted HCC children and found that the tumor size $(6.0 \pm 3.8$ $\mathrm{cm} v s 6.6 \pm 2.8 \mathrm{~cm}, p=0.7$ ), the rate of multiple tumors (44 vs $50 \%, p=1$ ), and the survival time (Supplementary material, Table S1, http://links.lww.com/A55; $p=0.14$, log-rank test, by Kaplan-Meier survival analysis) were not statistically different between two groups.

Pre-S2, rather than pre-S1 deletions, occurred exclusively in nearly half of the children with HCC. Further analysis of pre-S deletions (Table 3) indicated that $88.9 \%$ (eight of nine) of the pre-S deletions in the HCC group involved the pre-S2 region (Fig. 1, Supplementary material, Fig. S1, and Table 3, http://links.lww.com/A55). The deletion sizes ranged from 15 base pairs (bp) to $207 \mathrm{bp}$ (Table 3). In contrast, the only case of pre-S deletion in the chronic HBV infection group (Table 3, patient 5957) was in the pre-S1 region. Therefore, the HBV in the HCC group had a significantly higher rate of pre-S2 deletion than in the age-matched chronic HBV group (Table 1, 8 of $19 v s 0$ of $19, p=0.003$ ). There was no difference in the rates of pre-S1 deletion between the HCC and the chronic HBV infection groups (Table 1, 4 of $19 v s 1$ of $19 ; p=0.34$ ).

Functional sites potentially involved in $\mathrm{HCC}$-related pre-S deletions-focusing on the $N$-terminal half of pre-S2. To understand the possible impact of pre-S deletions on the function of $\mathrm{HBV}$, we analyzed the patterns of all HCC-related pre-S deletions (Fig. 1). Remarkably, we found that most (89\%, 8 of 9) of the pre-S deletions and all the pre-S2 deletions ( 8 of 8 ) involved a specific region-the N-terminal half of pre-S2 (Fig. 1 and Supplementary material, Fig. S1, http://links.lww.com/A55), followed by the C-terminal half of the pre-S1 region (44\%, four of nine). Therefore, the region extending from the $\mathrm{C}$-terminal half of pre-S1 to the $\mathrm{N}$-terminal half of pre-S2 seemed to be the preferred target region of deletion, and indeed, in two cases (patients 7 and 9; Fig. 1), the pre-S deletions included both the C-terminal half of pre-S1 and the N-terminal half of pre-S2. Several well-known B- and T-cell epitopes (Fig. 1) overlap with this region. Among them, the B-cell epitope at amino acids 120 to 145 was most frequently deleted (89\%, eight of nine; Fig. 1), followed by the

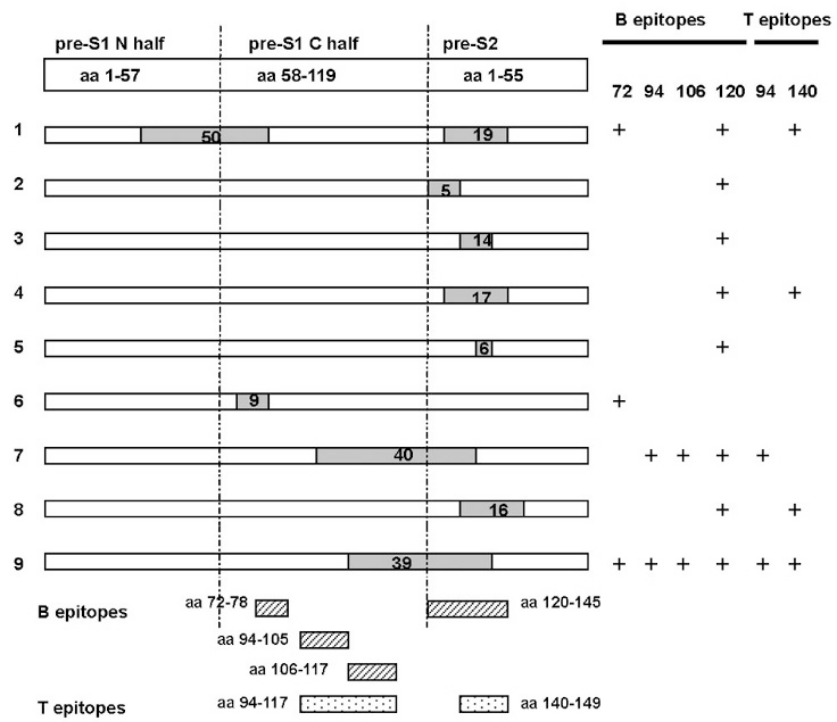

Figure 1. The positions of deleted amino acids (aa) and immunologic epitopes involved in nine HCC-related pre-S deletions. Each box represents the pre-S sequence of $\mathrm{HBV}$ in each case, with case numbers labeled in the left column. The pre-S region can be further divided into pre-S1 $\mathrm{N}$ half (aa 1-57), pre-S1 C half (aa 58-119), and pre-S2 (aa 1-55), as labeled above and in the uppermost box. The shaded area in each box represents the different deleted region in each case. The numbers inside shaded areas represent the size of aas deleted. No frame shift was caused by pre-S deletions in all cases. Shown below are boxes representing B- (slashed box) or T-cell (dotted box) epitopes. Only those B- or T-cell epitopes affected by our pre-S deletions are shown. For patient 1, another five B-cell epitopes within the pre-S N-terminal half were affected by the left-hand 50-aa deletion, but are not shown here due to limited space. The right column indicates B- or T-cell epitopes overlapping with the deleted regions. The numbers represent the first aa position of each epitope; e.g., 72 representing aa $72-78$, etc. The "+" represents presence of overlap.

T-cell epitope at amino acids 140 to 149 (44\%, four of nine; Fig. 1). In addition, we also determined which of the wellknown functional domains of HBV were potentially affected by these deletions (Table 4). The domains most frequently involved were the transactivator domain in pre-S2 (89\%) and the polymerized human serum albumin (PHSA)-binding site 
Table 4. The distribution of HCC-related pre-S deletions within HBV functional domains

\begin{tabular}{|c|c|c|c|c|c|c|c|c|c|}
\hline Patient No. & HSC70 & CAD & NBS & TD-1 & TD-2 & S-P & $\mathrm{CBF}$ & VS & PHSA \\
\hline 1 & $\mathrm{P}$ & - & $\mathrm{P}$ & $\mathrm{P}$ & $\mathrm{P}$ & $\mathrm{P}$ & - & $\mathrm{P}$ & $\mathrm{C}$ \\
\hline 2 & - & - & $\mathrm{P}$ & - & $\mathrm{P}$ & - & - & $\mathrm{C}$ & $\mathrm{P}$ \\
\hline 3 & - & - & $\mathrm{P}$ & - & $\mathrm{P}$ & - & - & - & $\mathrm{P}$ \\
\hline 4 & - & - & $\mathrm{P}$ & - & $\mathrm{P}$ & - & - & $\mathrm{P}$ & $\mathrm{P}$ \\
\hline 5 & - & - & - & - & $\mathrm{P}$ & - & - & - & $\mathrm{P}$ \\
\hline 6 & $\mathrm{P}$ & - & - & $\mathrm{P}$ & - & $\mathrm{P}$ & - & - & - \\
\hline 7 & $\mathrm{P}$ & $\mathrm{P}$ & $\mathrm{C}$ & - & $\mathrm{P}$ & $\mathrm{P}$ & $\mathrm{C}$ & $\mathrm{C}$ & $\mathrm{P}$ \\
\hline 8 & - & - & $\mathrm{P}$ & - & $\mathrm{P}$ & - & - & - & $\mathrm{P}$ \\
\hline 9 & $\mathrm{P}$ & $\mathrm{P}$ & $\mathrm{C}$ & $\mathrm{P}$ & $\mathrm{P}$ & $\mathrm{P}$ & $\mathrm{P}$ & $\mathrm{C}$ & $\mathrm{C}$ \\
\hline Involved $(\%)^{*}$ & 44 & 22 & 78 & 33 & 89 & 44 & 22 & 56 & 89 \\
\hline
\end{tabular}

* The percentage of deletion clones with the indicated functional domain involved.

HSC70, heat shock protein 70-binding site (aa 74-118); CAD, cytosolic anchorage determinant (aa 81-105); NBS, nucleocapsid binding site (aa 107-127); TD-1, transactivator domain in the pre-S1 region (aa 21-90); TD-2, transactivator domain in the pre-S2 region (aa 120-172); S-P, S-promoter (nt 3045-3180); CBF, CCAAT binding factor-binding site (nt 3137-3147); VS, viral secretion (aa 120-124); PHSA, polymerized human serum albumin-binding site (aa 122-135); P, partially overlaping with the deletions; $\mathrm{C}$, the functional domain was completely encompassed by the deletion; - , not involved by deletions.

(89\%), followed by the nucleocapsid binding site (78\%) and the domain responsible for viral secretion (56\%).

\section{DISCUSSION}

$\mathrm{HBV}$-related $\mathrm{HCC}$ is very rare in children, but such clinical samples (e.g., blood) are highly valuable for testing different hypotheses of the oncogenic mechanism of HBV, as cancers in children are less affected by environmental factors than the equivalent cancers in adults. Our study showed a significantly higher rate of pre-S2 deletions in the children of the HCC group than in the group with chronic HBV infection. The meaning of our results is unique and not merely in agreement with the studies in adults, because we found that pre-S2 deletions in HBV genomes did not necessarily take decades to accumulate, as in adult patients with advanced liver diseases $(1,15-22)$; they emerged in nearly half of the young children with HBV-related HCC that developed in a relatively short period of time.

Our results show that pre-S deletions in children are more often in the C-terminal half of the pre-S1 region and the $\mathrm{N}$-terminal half of the pre-S2 region, a continuous region that overlaps several B- or T-cell epitopes $(23,24)$. Such deletions, which were similar to those found in adults (20-22), may offer HBV mutants an advantage in escaping immune attack. This region also overlaps nine HBV domains with important functions (25-31). Four of them, including domains for PHSA binding, pre-S2 transactivator, nucleocapsid binding, and viral secretion, were more frequently involved in our pre-S deletion clones (Table 4). It has been suggested that functional impairment of nucleocapsid binding $(28,29)$ and PHSA binding $(31)$ caused by pre-S deletions may cause viral immaturities and create mutant viruses containing altered envelope proteins, respectively. Such immature or mutant viral particles tend to be retained intracellularly (16) and cause endoplasmic reticulum-stress $(32,33)$ that leads to oxidative stress and DNA damage (32), which may contribute to HCC formation. Nevertheless, we observed no significant difference between the HCC patients and non-HCC patients in terms of viral load (Table 1). One possible explanation is that almost all these patients were early $\mathrm{HBeAg}$ seroconverters. Hence, the viral loads of the majority (13 of 19 patients in HCC group and 14 of 19 patients in chronic HBV group) were so low (less than $10^{3}$ copies $/ \mathrm{mL}$, calculated as $10^{3}$ ) that the real-time PCR method we used (with a sensitivity around $10^{3}$ copies $/ \mathrm{mL}$ ) did not allow us to obtain exact values and distinguish the differences.

We reason that an interplay of genetic, immunologic, and viral factors may be responsible for early emergence of the HBV with pre-S2 deletions in children with HCC. For example, most of these children were likely to have acquired HBV infection perinatally, because most of their mothers were HBV carriers (3). Early $\mathrm{HBeAg}$ seroconversion is the other wellknown feature of these HCC children (2). Our results also indicated that in the HCC group, there was a trend toward a higher rate of pre-S2 deletion in genotype-C sera than in genotype-B sera ( $80 v s 29 \%, p=0.11)$, a phenomenon also observed in adults (34), but such a trend was not seen in our control group, because none of them had pre-S2 deletion. Lack of pre-S2 deletion in our chronic HBV infection group, which differs from what Lin et al. (34), Fang et al. (20), and Chen et al. (21) have reported in adults (12.4, 12.1, and $15.0 \%$, respectively), may be explained by the fact that the age of our control group (range, 11.3-14.2 y) was much younger than theirs (range, 17-79 y, 30-55 y, and 38.3-59.5 y, respectively). The duration of infection seemed to contribute to the accumulation of pre-S2 deletions in non-HCC adult patients with chronic HBV infection. However, early emergence of pre-S2 deletions is a unique feature in childhood HCC and suggests an important role in the early hepatocarcinogenesis in children. Alternatively, it is possible that the early onset of HCC was caused by host genetic predispositions to HCC, and the selection of the deletion mutants could represent the shutoff of HBV replication by cancerous tissues because they were less supportive of viral life cycle than untransformed hepatocytes. However, this possibility is less favored, because our observations (data not shown) and previous studies $(16,32,33)$ have shown that in the HCC livers, the characteristic immunostaining pattern of the large surface antigen with pre-S2 deletions is only found in the nontumor hepatocytes but not in the tumor cells.

In conclusion, our study of children with HBV-related HCC provides strong evidence that pre-S2 deletion is linked to HCC 
development. Thus, patients with pre-S2 deletions may benefit greatly from a more intensive follow-up strategy for early detection of HCC.

Acknowledgments. We thank Dr. Harry Wilson for suggestions and proofreading, and Dr. Mu-Zon Wu and Dr. YungMing Jeng for pathology consultation.

\section{REFERENCES}

1. Beasley RP, Hwang LY, Lin CC, Chien CS 1981 Hepatocellular carcinoma and hepatitis B virus. A prospective study of 22707 men in Taiwan. Lancet 2:11291133

2. Hsu HC, Wu MZ, Chang MH, Su IJ, Chen DS 1987 Childhood hepatocellular carcinoma develops exclusively in hepatitis B surface antigen carriers in three decades in Taiwan. Report of 51 cases strongly associated with rapid development of liver cirrhosis. J Hepatol 5:260-267

3. Chang MH, Hsu HY, Ni YH, Tsai KS, Lee PI, Chen PJ, Hsu YL, Chen DS 1998 Precore stop codon mutant in chronic hepatitis $\mathrm{B}$ virus infection in children: its relation to hepatitis $\mathrm{B}$ e seroconversion and maternal hepatitis B surface antigen. J Hepatol 28:915-922

4. Ni YH, Chang MH, Wang KJ, Hsu HY, Chen HL, Kao JH, Yeh SH, Jeng YM, Tsai KS, Chen DS 2004 Clinical relevance of hepatitis B virus genotype in children with chronic infection and hepatocellular carcinoma. Gastroenterology 127:1733-1738

5. Ni YH, Chang MH, Hsu HY, Tsuei DJ 2004 Longitudinal study on mutation profiles of core promoter and precore regions of the hepatitis B virus genome in children. Pediatr Res 56:396-399

6. Ni YH, Chang MH, Hsu HY, Tsuei DJ 2003 Different hepatitis B virus core gene mutations in children with chronic infection and hepatocellular carcinoma. Gut 52:122-125

7. Naoumov NV, Schneider R, Grotzinger T, Jung MC, Miska S, Pape GR, Will H 1992 Precore mutant hepatitis B virus infection and liver disease. Gastroenterology 102:538-543

8. Kao JH, Chen PJ, Lai MY, Chen DS 2003 Basal core promoter mutations of hepatitis $\mathrm{B}$ virus increase the risk of hepatocellular carcinoma in hepatitis B carriers. Gastroenterology 124:327-334

9. Bruix J, Sherman M 2005 Management of hepatocellular carcinoma. Hepatology 42:1208-1236

10. Yeh SH, Tsai CY, Kao JH, Liu CJ, Kuo TJ, Lin MW, Huang WL, Lu SF, Jih J, Chen DS, Chen PJ 2004 Quantification and genotyping of hepatitis B virus in a single reaction by real-time PCR and melting curve analysis. J Hepatol 41:659-666

11. Chen BF, Liu CJ, Jow GM, Chen PJ, Kao JH, Chen DS 2006 Evolution of Hepatitis $\mathrm{B}$ virus in an acute hepatitis B patient co-infected with genotypes B and C. J Gen Virol 87:39-49

12. Kwok S, Higuchi R 1989 Avoiding false positives with PCR. Nature 339:237-238

13. Thompson JD, Higgins DG, Gibson TJ 1994 CLUSTAL W: improving the sensitivity of progressive multiple sequence alignment through sequence weighting, position-specific gap penalties and weight matrix choice. Nucleic Acids Res 22:4673-4680

14. Rice P, Longden I, Bleasby A 2000 EMBOSS: the European Molecular Biology Open Software Suite. Trends Genet 16:276-277

15. Pollicino T, Zanetti AR, Cacciola I, Petit MA, Smedile A, Campo S, Sagliocca L, Pasquali M, Tanzi E, Longo G, Raimondo G 1997 Pre-S2 defective hepatitis B virus infection in patients with fulminant hepatitis. Hepatology 26:495-499
16. Fan YF, Lu CC, Chen WC, Yao WJ, Wang HC, Chang TT, Lei HY, Shiau AL, Su IJ 2001 Prevalence and significance of hepatitis B virus (HBV) pre-S mutants in serum and liver at different replicative stages of chronic HBV infection. Hepatology 33:277-286

17. Huy TT, Ushijima H, Win KM, Luengrojanakul P, Shrestha PK, Zhong ZH, Smirnov AV, Taltavull TC, Sata T, Abe K 2003 High prevalence of hepatitis B virus pre-s mutant in countries where it is endemic and its relationship with genotype and chronicity. J Clin Microbiol 41:5449-5455

18. Sugauchi F, Ohno T, Orito E, Sakugawa H, Ichida T, Komatsu M, Kuramitsu T, Ueda R, Miyakawa Y, Mizokami M 2003 Influence of hepatitis B virus genotypes on the development of preS deletions and advanced liver disease. J Med Virol 70:537-544

19. Choi MS, Kim DY, Lee DH, Lee JH, Koh KC, Paik SW, Rhee JC, Yoo BC 2007 Clinical significance of pre-S mutations in patients with genotype $\mathrm{C}$ hepatitis $\mathrm{B}$ virus infection. J Viral Hepat 14:161-168

20. Fang ZL, Sabin CA, Dong BQ, Wei SC, Chen QY, Fang KX, Yang JY, Huang J, Wang XY, Harrison TJ 2008 Hepatitis B virus pre-S deletion mutations are a risk factor for hepatocellular carcinoma: a matched nested case-control study. J Gen Virol 89:2882-2890

21. Chen CH, Changchien CS, Lee CM, Hung CH, Hu TH, Wang JH, Wang JC, Lu SN 2008 Combined mutations in pre-s/surface and core promoter/precore regions of hepatitis B virus increase the risk of hepatocellular carcinoma: a case-control study. J Infect Dis 198:1634-1642

22. Chen BF, Liu CJ, Jow GM, Chen PJ, Kao JH, Chen DS 2006 High prevalence and mapping of pre-S deletion in hepatitis B virus carriers with progressive liver diseases. Gastroenterology 130:1153-1168

23. Milich DR, Thornton GB, Neurath AR, Kent SB, Michel ML, Tiollais P, Chisari FV 1985 Enhanced immunogenicity of the pre-S region of hepatitis B surface antigen. Science 228:1195-1199

24. Milich DR, McLachlan A, Chisari FV, Thornton GB 1986 Nonoverlapping T and B cell determinants on an hepatitis B surface antigen pre-S(2) region synthetic peptide. J Exp Med 164:532-547

25. Bruss V, Vieluf K 1995 Functions of the internal pre-S domain of the large surface protein in hepatitis B virus particle morphogenesis. J Virol 69:6652-6657

26. Hildt E, Urban S, Hofschneider PH 1995 Characterization of essential domains for the functionality of the MHBst transcriptional activator and identification of a minimal MHBst activator. Oncogene 11:2055-2066

27. Kim HS, Ryu CJ, Hong HJ 1997 Hepatitis B virus preS1 functions as a transcriptional activation domain. J Gen Virol 78:1083-1086

28. Poisson F, Severac A, Hourioux C, Goudeau A, Roingeard P 1997 Both pre-S1 and $\mathrm{S}$ domains of hepatitis B virus envelope proteins interact with the core particle. Virology 228:115-120

29. Le Seyec J, Chouteau P, Cannie I, Guguen-Guillouzo C, Gripon P 1998 Role of the pre-S2 domain of the large envelope protein in hepatitis B virus assembly and infectivity. J Virol 72:5573-5578

30. Bock CT, Kubicka S, Manns MP, Trautwein C 1999 Two control elements in the hepatitis B virus S-promoter are important for full promoter activity mediated by CCAAT-binding factor. Hepatology 29:1236-1247

31. Sobotta D, Sominskaya I, Jansons J, Meisel H, Schmitt S, Heermann KH, Kaluza G, Pumpens P, Gerlich WH 2000 Mapping of immunodominant B-cell epitopes and the human serum albumin-binding site in natural hepatitis B virus surface antigen of defined genosubtype. J Gen Virol 81:369-378

32. Hsieh YH, Su IJ, Wang HC, Chang WW, Lei HY, Lai MD, Chang WT, Huang W 2004 Pre-S mutant surface antigens in chronic hepatitis B virus infection induce oxidative stress and DNA damage. Carcinogenesis 25:2023-2032

33. Wang HC, Huang W, Lai MD, Su IJ 2006 Hepatitis B virus pre-S mutants, endoplasmic reticulum stress and hepatocarcinogenesis. Cancer Sci 97:683-688

34. Lin CL, Liu CH, Chen W, Huang WL, Chen PJ, Lai MY, Chen DS, Kao JH 2007 Association of pre-S deletion mutant of hepatitis B virus with risk of hepatocellular carcinoma. J Gastroenterol Hepatol 22:1098-1103 